\title{
Dissimilarity between Andropogon lateralis ecotypes under different defoliation frequencies and heights
}

\author{
Thiago Barros ${ }^{1}$ (i) Roberto Luis Weiler $^{1}$ (D) Juliana Medianeira Machado $^{2,3^{*}}$ (D) \\ Diógenes Cecchin Silveira ${ }^{1}$ (D) André Pich Brunes ${ }^{1}$ (i) Annamaria Mills $^{4}($ (D) \\ Carine Simioni ${ }^{1}$ (i) Miguel Dall'Agnol $^{1}$ [D
}

${ }^{1}$ Universidade Federal do Rio Grande do Sul (UFRGS), Porto Alegre, RS, Brasil.

${ }^{2}$ Universidade Federal de Santa Maria (UFSM), Departamento de Zootecnia, Santa Maria, RS, Brasil.

${ }^{3}$ Universidade de Cruz Alta (UNICRUZ), Cruz Alta, RS, Brasil. E-mail: julianam.machado@yahoo.com.br. *Corresponding author .

${ }^{4}$ Lincoln University New Zealand (LUNZ), Lincoln, NZ, New Zeland.

ABSTRACT: Andropogon lateralis Nees is a native grass of southern Brazil and is one of the most frequent specie found in native grasslands. The species is widely distributed and has a high degree of phenotypic plasticity, which makes it highly adaptable to different edaphoclimatic conditions and management. This study aimed to evaluate the behavior of twelve ecotypes of A. lateralis, collected in different regions of the state of Rio Grande do Sul and cut to three different heights and subjected to two different defoliation frequencies. From September to February, the ecotypes were evaluated for total dry matter, leaf and stem yields. In addition, total, vegetative and reproductive tillers and plant height were measured. These characteristics are important for the selection of superior genotypes in terms of genetic variability and forage production. Total dry matter and leaf dry matter are characteristics with agronomic importance and they showed the highest correlation $(r=0.77)$, enabling an indirect selection for one of these characteristics. The natural selection of plants resulted in distinct structural, morphological and productive characteristics with heterogeneity that allows the selection and grouping according to the characteristics, ecotypes with superior agronomic characteristics can be included in breeding programs.

Key words: agronomic characteristics, correlation, cut management, native grass.

Dissimilaridade entre ecótipos de Andropogon lateralis submetidos a diferentes frequências de desfolha e alturas de corte

RESUMO: Andropogon lateralis Nees é uma gramínea nativa do sul do Brasil e uma das espécies mais frequentes na flora dos campos nativos da região. Possui ampla distribuição e alto grau de plasticidade fenotípica, tornando-o adaptável as condições edafoclimáticas e a práticas de desfolha. Este estudo teve como objetivo avaliar a dissimilaridade entre doze ecótipos de A. lateralis $N$., coletados em diferentes regiões do Rio Grande do Sul, submetidos a duas frequências de desfolha e três alturas de corte. No período de setembro a fevereiro, os ecótipos foram avaliados quanto à produção de matéria seca total, de lâminas foliares e de colmo. Além disso, foram medidos o número de perfilhos totais, vegetativos e reprodutivos e a altura das plantas. Essas características são importantes para a seleção de genótipos superiores em termos de variabilidade genética e produção de forragem. A matéria seca total e a matéria seca foliar são características com importância agronômica e apresentaram a maior correlação $(r=0,77)$, possibilitando uma seleção indireta para uma dessas características. A seleção natural das plantas resultou em características estruturais, morfológicas e produtivas distintas com uma heterogeneidade que permite a seleção e agrupamento de acordo com as características, ecótipos com características agronômicas superiores podem ser incluídos em programas de melhoramento.

Palavras-chave: caracteres agronômicos, correlação, gramínea nativa, práticas de desfolha.

\section{INTRODUCTION}

The flora of native grasslands in Southern Brazil includes several species with good forage characteristics from the $>400$ grasses and 150 legumes currently identified (BOLDRINI, 1997). Several of these species have a high number of regional ecotypes which have adapted to the local edaphoclimatic conditions, which represents a unique source of forage germoplasm, but there have been few studies which describe the uses and potential of these plants for forage production (STEINER et al., 2017; SARAIVA et al., 2021).

Native grasslands are an important food source for herbivores, with the area occupied by non-forest ecosystems accounting for $\sim 30 \%$ of the country's total area (OVERBECK et al., 2015). However, over the last five decades these areas have been replaced by crops, forestry, cities and urban spread or exotic forage. Native grasslands have not been considered a conservation priority in southern Brazil, despite losing $>50 \%$ of the original 
area, high natural biodiversity (flora and fauna) and the important ecosystem services they contribute (MENEZES et al., 2015). Poor management has decimated this habitat but, when managed with optimal stocking rates combined with appropriate grazing management, this critically important natural resource presents favorable economical results to producers and preserves existing biodiversity for future generations.

Andropogon lateralis Nees is one of the most frequent native species found in native grasslands in the state of Rio Grande do Sul (RS/Brazil) and is important due to its wide ecophysiological distribution (ANDRADE et al., 2016). It is a perennial, tussocktype grass and most dry matter production occurs in spring and summer (ANDRADE et al., 2019). It is characterized as a species with substantial phenotypic plasticity when exposed to abiotic factors (such as drought, frost, etc.) and those imposed by management (fire, grazing, mowing), which result in different defoliation intensities and frequencies. Physiological differences among ecotypes include changing the growth habits, the proportion of leaves, stems and nutritional quality (BOLDRINI, 1997; TRINDADE \& ROCHA, 2001).

Identifying the optimum defoliation regime will optimize management and utilization, with canopy structures that allow rapid regrowth extremely important. The canopy structure should allow animals to ingest material with high contribution of young palatable leaves and stems, and management decisions which result in senescence and stem elongation should be minimized (PRADO et al., 2019). However, there is still little research for most native species. Furthermore, there are presently no cultivars of $A$. lateralis $\mathrm{N}$. commercially available and studies that evaluate the variability among ecotypes can contribute to identifying superior plants for selection and inclusion in breeding programs. Selection due to natural variability of materials has been one of the main methods of cultivar development for native forages in Brazil (DO VALLE et al., 2009) and globally.

This study aimed to evaluate the dissimilarity between ecotypes of A. lateralis N., collected in different regions of Rio Grande do Sul/ Brazil, at two defoliation frequencies and three cutting heights to simulate different defoliation intensities. The morphophysiological responses of the ecotypes were evaluated in order to understand plant growth enabling better management of this species and identify promising genetic material for use in breeding programs for forage production.

\section{MATERIALS AND METHODS}

The experiment was conducted at the Department of Forage Plants and Agrometeorology in the Agronomics School of the Federal University of Rio Grande do Sul. Ecotypes were collected in different physiographic regions of the state of Rio Grande do Sul. A total of 12 ecotypes were collected from Alegrete, Bagé, Caçapava do Sul, Capivari do Sul, Eldorado do Sul, Mariana Pimentel, Montenegro, Passo Fundo, Pelotas, Piratini, Soledade and Tapes.

The plants were kept in a greenhouse during the autumn and winter and in spring were transplanted into $2.8 \mathrm{~L}$ pots $(22 \mathrm{~cm}$ high $\times 22 \mathrm{~cm}$ diameter) and transferred outside the greenhouse. A commercial substrate was used. On September $15^{\text {th }} 5.0 \mathrm{~g} \mathrm{~N}-\mathrm{P}-\mathrm{K}$ (05:20:20) fertilizer was applied with an additional $5.0 \mathrm{~g}$ of urea $(45 \% \mathrm{~N})$ applied per pot on September $28^{\text {th }}$. The evaluations were carried out during one period active of growth (which encompassed spring, summer and autumn). Pots were irrigated until soil saturation every seven days without precipitation.

A completely randomized factorial design was used with 72 treatments: twelve ecotypes, three defoliation heights $(\mathrm{H}=6 \mathrm{~cm}, 12 \mathrm{~cm}$ or $18 \mathrm{~cm}$ residuals $)$ and two defoliation frequencies (F) (3 weeks or 6 weeks), with four replicates. The ecotypes were named by defoliation frequency ( 3 or 6 weeks), defoliation cutting height $(6,12$ or $18 \mathrm{~cm})$ and the location the ecotype came from. Seedlings with the same number of tillers were used. Initially, plants were cut to a standardized height, the evaluations started when the plants were $\sim 25 \mathrm{~cm}$ high. Subsequent cuts were in accordance with the pre-established defoliation frequencies ( 3 or 6 weeks). At each evaluation, the number of vegetative and reproductive tillers of each plant were counted. Reproductive tillers were those where there was already differentiation that demonstrated the flowering induction of that stem. The plant height was measured with a graduated scale, from the soil surface to the extremity of the highest leaf of the plant. The experiment was concluded when there was a reduction in plant growth, possibly due to a reduction in photoperiod and temperature.

After cutting, samples were morphologically separated into leaf blades, stems and dead material, then placed in a forced air circulation chamber at $65{ }^{\circ} \mathrm{C}$ until constant weight. Variables quantified were accumulated total dry mass (TDM, grams plant ${ }^{-1}$ ), both for the accumulated forage above the cutting height, accumulated leaf blades dry matter (LDM, g plant ${ }^{-1}$ ), accumulated stem dry matter (SDM, $\mathrm{g} \mathrm{plant}^{-1}$ ), total number of vegetative tillers (NVT), 
total number of reproductive tillers (NRT), number total of tillers (NTT) and plant height (PH, cm). The leaf:stem ratio (L:S) was obtained by dividing the dry leaf matter by stem dry matter. The data were submitted to Pearson's correlation analysis. The magnitudes of correlation coefficients were classified according to SILVEIRA et al. (2020). The cluster analysis used to assess genetic dissimilarity between treatments was performed using the Tocher optimization method based on the generalized Mahalanobis distance $\left(D^{2}\right)$ using the statistical program GENES (CRUZ, 2016).

\section{RESULTS AND DISCUSSION}

Knowledge of the factors that affect the productivity of pastures is essential to make the production system viable. In the present study, the phenotypic correlation was determined for the variables and is presented through a correlation network (Figure 1). The correlation coefficients ranged from 0.26 (NVT and NRT) to 0.85 (TDM and SDM).
There were significant correlations and with different magnitudes of response between most of the variables studied. Specifically, TDM showed significant strong correlation with LDM and SDM, with correlation coefficients of $\mathrm{r}=0.77(\mathrm{P} \leq 0.01)$ and $0.85(\mathrm{P} \leq 0.01)$, respectively. The variables NTT, NRT, NVT and PH also showed significant mean correlations $(\mathrm{r}=0.53$ $(\mathrm{P} \leq 0.01) ; 0.45 \quad(\mathrm{P} \leq 0.01) ; 0.40 \quad(\mathrm{P} \leq 0.01)$ and 0.35 $(\mathrm{P} \leq 0.01)$, respectively) with TDM. Both TDM and LDM are the characteristics of greatest agronomic importance, as they are related to the production of forage accumulated in the experimental period and contribute to the quality of forage on offer to grazing stock. The selection to increase the production of leaf blades has been strongly advocated in the improvement of forages (WEILER et al., 2018), as the best nutritional quality is found in the green leaf blade and animals have a preference for this structure during grazing (SOLLENBERGER \& BURNS, 2001). In this study, the high correlation $(r=0.77)$, observed between these characteristics is positive,

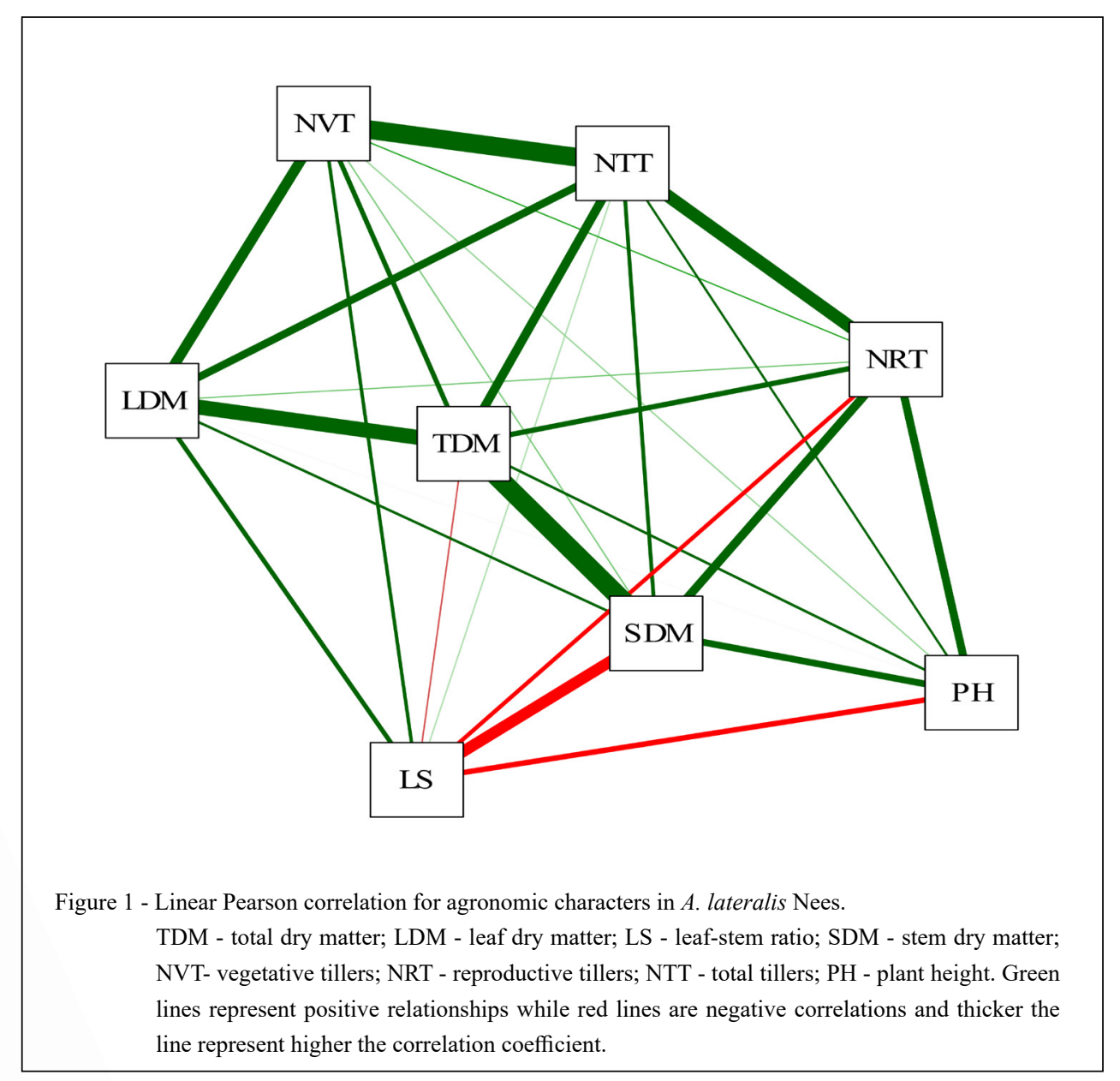

Ciência Rural, v.52, n.3, 2022. 
because when selecting one of these resources, the other is also indirectly being favored.

LDM showed a significant correlation with the variables NVT, NTT, LS and SDM, with correlation coefficients of $\mathrm{r}=0.57(\mathrm{P} \leq 0.01), 0.52(\mathrm{P} \leq 0.01), 0.39$ $(\mathrm{P} \leq 0.01)$ and $0.34(\mathrm{P} \leq 0.01)$, respectively (Figure 1). For each leaf blade formed there is a new phytomer and buds that will be responsible for the origin of new tillers when they receive light stimuli (CUTRIM et al., 2013). Thus, the median correlation observed between LDM, NVT and NTT, may infer that the defoliation management practices tested favored the renewal of plant tissues. In addition, the number of tillers is an agronomic indicator of growth, productivity and pasture persistence (SCHENEITER \& ASSUERO, 2010). However, selection for tillering in plant breeding has been questioned as a selection criterion for all species (FASOULA et al., 2020), due to the complexity of genetic control and also due to the differential response to edaphoclimatic conditions and management systems (CORROCHANOMONSALVE et al., 2020).

As the ecotypes originated from different regions and microclimates, natural selection had resulted in different structural, morphological and productive characteristics and, consequently, heterogeneity. For breeding purposes this allows the selection, differentiation and grouping of treatments according to their characteristics, allowing ecotypes with superior agronomic characteristics. The cluster analysis methodology optimized by the Tocher (Table 1) showed three groups, with a high concentration of accessions in group I (91.7\%). This type of distribution shows a high similarity between the treatments studied (KAUR et al., 2018). The species has a wide distribution and a high degree of phenotypic plasticity, making it adaptable to edaphoclimatic conditions and defoliation practices (TRINDADE \& ROCHA, 2001; MACHADO et al., 2013). The effect of phenotypic plasticity found in $A$. lateralis may have contributed to the high similarity between the treatments tested. The presence of plasticity was evident in this study. Specifically, under different management it can behave as a plant of resource capture or conservation according the defoliation intensity imposed.

The low dissimilarity between the ecotypes indicates that the genetic progress of breeding with the selected quantitative characteristics can be limited. Despite the similarity between the treatments, considering the composition of the groups (Table 1), the Mahalanobis distance matrix $\left(\mathrm{D}^{2}\right)$ showed high amplitude, and ranged from 0.01 to 3017 . Treatments 312 Soledade and 612Soledade were the most similar $\left(D^{2}=0.01\right)$, while treatments 66Bagé and 618Mariana Pimentel were the most distant $\left(\mathrm{D}^{2}=\right.$ 3017). The presence of variability allows the use of this germplasm in breeding programs for $A$. lateralis and ecotypes with greater distance can be use in future crosses (GUEDES et al., 2013).

Table 1 - Composition of groups formed by the Tocher optimization method based on the Mahalanobis distance matrix (D ${ }^{2}$ ) in $A$. lateralis Nees. Treatments are specified by defoliation frequency ( 3 or 6 weeks), defoliation cutting height $(6,12$ or $18 \mathrm{~cm})$ and the location the ecotype came from.

Group
312Soledade; 612Soledade; 612Capivari; 618Piratini; 618Capivari; 66Alegrete; 618Pelotas; 312Alegrete; 66Piratini;
318Tapes; 318Capivari; 318Alegrete; 612Alegrete; 612Montenegro; 312Capivari; 312Pelotas; 612Caçapava;
66Caçapava; 66Marianapim; 618Eldorado; 618Soledade; 312PassoFundo; 66Soledade; 612Eldorado;
318Caçapava; 618Marianapim; 36Tapes; 612Marianapim; 66Capivari; 312Piratini; 318PassoFundo;
318Marianapim; 318Montenegro; 618Montenegro; 312Montenegro; 36Soledade; 612Tapes; 612Piratini;
618Caçapava; 618Tapes; 36Eldorado; 66Montenegro; 318Soledade; 318Piratini; 36Montenegro; 36Pelotas;
66Eldorado; 318Eldorado; 36Marianapim; 36PassoFundo; 312Marianapim; 312Caçapava; 618Alegrete;
318Pelotas; 312Tapes; 36Capivari; 312Eldorado; 66PassoFundo; 36Alegrete; 36Piratini; 612Pelotas;
618PassoFundo; 36Caçapava; 66Tapes; 612Bagé; 66Pelotas
36Bagé; 318Bagé; 312Bagé; 612PassoFundo; 618Bagé
II

Significance levels are: ${ }^{*}=\mathrm{P} \leq 0.05^{* *}=\mathrm{P} \leq 0.01$ from t-tests; TDM - total dry matter; LDM - leaf dry matter; LC - leaf-stem ratio; SDM stem dry matter; NVT- vegetative tillers; NRT - reproductive tillers; NTT - total tillers; PH - plant height. 
The accumulation of dry matter is linked to defoliation practices, specifically the frequency and intensity with which these events occur (LEMAIRE et al., 2009). Thus, the structural components of the plant can be used as objective measures in the processes of harvesting and using the forage produced (GRIFFITHIS et al., 2003). The variables with the greatest relative contribution to genetic dissimilarity (Figure 2) are allocated to Group III (Table 1). In this analysis, 66Bagé presented higher mean LS and NVT, and a lower mean for SDM and $\mathrm{PH}$, in relation to treatments allocated to Groups I and II. The lower plant height favored desired structural characteristics. This was confirmed by the negative correlations obtained between PH and LS and positive correlations between PH and SDM (Figure 1). Group III concentrated $1.38 \%$ of each combination between the factors (frequency, height and ecotype). Group I (Table 1), on the other hand, had lower LS and NVT compared to the other groups (II and III) and higher SDM and PH. Therefore, the highest residual cutting heights had a negative impact on the performance of the treatments assigned to Group I. The highest
SDM characterized the structure of the plants that make up the treatments of Group 1 which have the lowest nutritional value (STOBBS, 1973). Group I concentrated $15.3 \%$ of each combination between the factors (frequency, height and ecotype). For the four variables with the greatest relative contribution (Figure 2), Group II presented intermediate values compared with Groups I and III (Table 1). Group II concentrated $6.94 \%$ of each combination between the factors (frequency, height and ecotype).

Morphological characteristics are commonly used to assess dissimilarity between ecotypes. These variables are commonly quantified in germplasm evaluations and characterization, and can be related to adaptability, stability and productive potential of the species/ecotype being evaluated (GRAMINHO et al., 2017; STRECK et al., 2017). In our study, the variables that most contributed to genetic dissimilarity were LS, NVT, SDM and $\mathrm{PH}$, which accounted for $83.8 \%$ of the dissimilarity between the treatments imposed. Singh (1981) also indicated the importance of identifying the characteristic(s) responsible for the majority

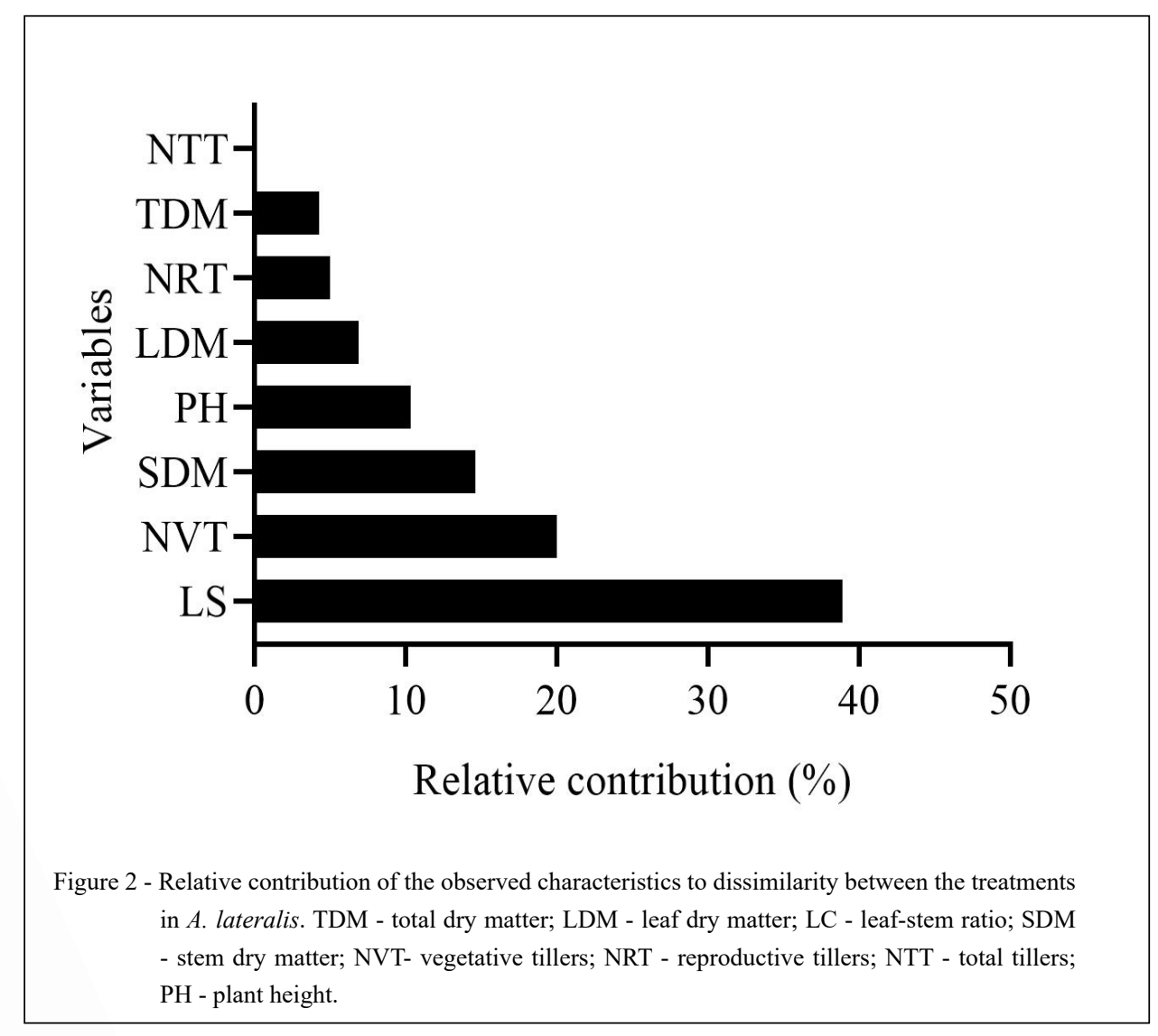

Ciência Rural, v.52, n.3, 2022. 
of dissimilarity and it is efficient in pointing out the variables of possible disposal. In this work, NRT and NTT could be considered less important selection criteria, as they contributed only $4.26 \%$ to dissimilarity (Figure 2). The selection of genotypes for breeding based only on genetic divergence, without considering characteristics of interest, can be an inefficient strategy in a breeding program (CARPENTIERI-PÍPOLO et al., 2000). This work identifies charateristics of interest and assigned ecotypes to groups to aid breeding programs in identifying material with dissimilar traits.

\section{CONCLUSION}

In this study we evaluated important characteristics for the selection of superior ecotypes in terms of genetic variability and forage production for Andropogon lateralis. Total dry matter and leaf dry matter were the main characteristics with agronomic importance and had the highest correlation, enabling an indirect selection for one of these characteristics.

Natural selection of plants within defined ecophysiological environments has created ecotypes with distinct structural, morphological and productive characteristics with a heterogeneity which can be selected and grouped allowing ecotypes with superior agronomic characteristics to be included in breeding programs.

\section{ACKNOWLEDGEMENTS}

We thank the Conselho Nacional de Desenvolvimento Científico e Tecnológico (CNPq), Brazil - Fiance code $132455 / 2010-2$

\section{DECLARATION OF CONFLICT OF INTEREST}

We have no conflict of interest to declare.

\section{AUTHORS' CONTRIBUTIONS}

All authors contributed equally for the conception and writing of the manuscript. All authors critically revised the manuscript and approved of the final version.

\section{REFERENCES}

ANDRADE, B. O. et al. Highland grasslands at the Southern tip of the Atlantic Forest biome: Management options and conservation challenges. Oecologia Australis, v. 20, p. 37-71, 2016. Available from: $<$ https://revistas.ufrj.br/index.php/oa/article/view/8358/0>. Accessed: Jul. 10, 2020. doi: 10.4257/oeco.2016.2002.04.
ANDRADE, B. O. et al. Classification of South Brazilian grasslands: Implications for conservation. Applied Vegetation Science, v. 22, p. 168-184, 2019. Available from: <https:// onlinelibrary.wiley.com/doi/full/10.1111/avsc.12413>. Accessed: Jun. 20, 2020. doi: 10.1111/avsc. 12413.

BOLDRINI, I. I. Campos do Rio Grande do Sul: Caracterização fisionômica e problemática ocupacional. Porto Alegre: Instituto de Biociências Universidade Federal do Rio Grande do Sul, 1997. 39 p. (Boletim técnico, 56).

CARPENTIERI-PÍPOLO, V. et al. West Indian Cherry parental genotype selection based on multivariate genetic divergence. Pesquisa Agropecuária Brasileira, v. 35, p. 1613-1619, 2000. Available from: $<$ https://www.scielo.br/scielo.php?pid=S0100$204 X 2000000800014 \&$ script $=$ sci_abstract\&tlng=pt $>$. Accessed: May. 05, 2021. doi:10.1590/S0100-204X2000000800014.

CORROCHANO-MONSALVE, M. et al. Relationship between tillage management and DMPSA nitrification inhibitor efficiency. Science of the Total Environment, v. 718, p. 134748, 2020. Available from: $<$ https://www.sciencedirect.com/science/ article/pii/S0048969719347394>. Accessed: Sep. 02, 2020. doi: 10.1016/j.scitotenv.2019.134748.

CRUZ, C. D. Genes Software-extended and integrated with the R, Matlab and Selegen. Acta Scientiarum, v. 38, p. 547-552, 2016. Available from: <https://www.scielo.br/pdf/asagr/v38n4/18078621-asagr-38-04-00547.pdf $>$. Accessed: May. 03, 2021. doi: 10.4025/actasciagron.v38i4.32629.

CUTRIM JR., J. A. A. et al. Biomass flow in tifton -85 bermudagrass canopy subjected to different management strategies under rotational grazing with dairy goats. Revista Brasileira de Zootecnia, v. 42, p. 77 - 86, 2013. Available from: $<$ https://www.scielo.br/j/rbz/a/SwGzcYKxSkYLfxKKqXvkQ vj/?lang=en>. Accessed: May. 08, 2021. doi: 10.1590/S151635982013000200001 .

DO VALLE, C.B. et al. O melhoramento de forrageiras tropicais no Brasil. Revista Ceres, v. 56, p. 460-472, 2009. Available from: $<$ http://www.ceres.ufv.br/ojs/index.php/ceres/article/view/3454>. Accessed: Sep. 01, 2020.

FASOULA, D. A. et al. Phenotyping and Plant Breeding: Overcoming the Barriers. Frontiers in Plant Science, v. 10, p. 1713, 2018. Available from: <https://www.frontiersin.org/ articles/10.3389/fpls.2019.01713/full>. Accessed: Oct. 08, 2020. doi: $10.3389 /$ fpls.2019.01713.

GRAMINHO, L. A. et al. Forage characters of different Paspalum species in Rio Grande do Sul: a meta-analysis. Ciência Rural, v. 47, p. e20161049, 2017. Available from: <https://www.scielo.br/j/ $\mathrm{cr} / \mathrm{a} /$ VNgfqjLTgYkSBHXgJ7BYfnQ/?lang=en>. Accessed: May. 20, 2021. doi: 10.1590/0103-8478cr20161049.

GRIFFITHIS, W. M. et al. The influence of sward canopy structure on foraging decisions by grazing cattle. II. Regulation of bite depth. Grass and Forage Science, v. 58, p. 125-137, 2003. Available from: $<$ https://onlinelibrary.wiley.com/doi/abs/10.10 46/j.1365-2494.2003.00361.x>. Accessed: May. 02, 2021. doi: 10.1046/j.1365-2494.2003.00361.x.

GUEDES, J. M. et al. Divergência genética entre cafeeiros do germoplasma Maragogipe. Bragantia, v. 72, p. $127-$ 132, 2013. Available from: <https://www.scielo.br/j/brag/a/ 
BxjnKBsXk5cwhV8TH7cmCDH/abstract/?lang=pt>. Accessed: May. 02, 2021. doi: 10.1590/S0006-87052013000200003.

KAUR, R. et al. Assessing genetic diversity in dual purpose oat (Avena sativa L.) cultivars based on morphological and quality traits. International Journal of Current Microbiology and Applied Sciences, v. 7, p. 1574-1586, 2018. Available from: $<$ https:/www.ijcmas.com/abstractview.php?ID=7888\&vol=75-2018\&SNo=187>. Accessed: May. 02, 2021. doi: 10.20546/ ijcmas.2018.705.187.

LEMAIRE, G. et al. Interactions between leaf lifespan and defoliation frequency in temperate and tropical pastures: a review. Grass and Forage Science, v. 64, p. 341-353, 2009. Available from: $<$ https://onlinelibrary.wiley.com/doi/10.111 1/j.1365-2494.2009.00707.x>. Accessed: Jul. 13, 2020. doi: 10.1111/j.1365-2494.2009.00707.x

MACHADO, J. M. et al. Morphogenesis of native grasses of Pampa Biome under nitrogen fertilization. Revista Brasileira de Zootecnia, v. 42, p. 22-29, 2013. Available from: <https://www. scielo.br/scielo.php?script $=$ sci arttext\&pid $=\mathrm{S} 1516359820130001$ 00004\&lng=en\&nrm=iso $>$. Accessed: Jul. 13, 2020. doi: 10.1590/ S1516-35982013000100004

MENEZES, L. S. et al. Floristic and structural patterns in South Brazilian coastal grasslands. Anais da Academia Brasileira de Ciências, v. 87, p. 2081-2090, 2015. Available from: $\quad<$ https://www.scielo.br/scielo.php?script=sci_arttext\&pid $=$ S0001-37652015000502081 $>$. Accessed: Aug. 14, 2020. doi: 10.1590/0001-3765201520140555.

OVERBECK, G. E. et al. Conservation in Brazil needs to include non-forest ecosystems. Diversity and Distributions, v. 21, p. 1455-1460, 2015. Available from: <https://onlinelibrary.wiley. com/doi/10.1111/ddi.12380>. Accessed: Nov. 03, 2020. doi: $10.1111 /$ ddi. 12380

PRADO, D. A. et al. Morphogenetic and structural characteristics, yield and chemical composition of signal grass under deferred grazing. Biological Rhythm Research, 2019. Available from: <https://www.tandfonline.com/doi/abs/10.10 80/09291016.2019.1621062>. Accessed: Jan. 10, 2020. doi: 10.1080/09291016.2019.1621062.

SARAIVA, K. M. et al. Hybrids of Paspalum plicatulum $\times P$. guenoarum: selection for forage yield and cold tolerance in a subtropical environment. Tropical Grasslands - Forrajes Tropicales, v. 9, p. 138-143, 2021. Available from: <https:// www.tropicalgrasslands.info/index.php/tgft/article/view/504>. Accessed: May. 20, 2021. doi: 10.17138/tgft(9)138-143.

SCHENEITER, J.; ASSUERO, S. Tiller population density and productivity in tall fescue and prairie grass swards. Ciencia e
Investigación Agraria, v. 37, p. 35-44, 2010. Available from: $<$ http://mail.ijanr.cl/index.php/ijanr/article/view/168>. Accessed: May. 20, 2021. doi: 10.4067/S0718- 16202010000200004.

SILVEIRA, D. C. et al. Anatomical Traits and Structural Components of Peduncle Associated with Lodging in Avena Sativa L. Agronomy Research, v. 19, p. 250-264, 2021. Available from: <https://agronomy.emu.ee/wpcontent/uploads/2021/01/ AR2020_444_Silveira_V_doi_001.pdf >. Accessed: May. 03, 2021. doi: $10 . \overline{1} 15159 / \mathrm{AR} \cdot \overline{21} \cdot 00 \overline{1}$.

SINGH, D. The relative importance of characters affecting genetic divergence. Indian Journal Genetic Plant Breeding, v. 41, p. $237-245,1981$

STEINER, M. G. et al. Forage potential of native ecotypes of Paspalum notatum and P. guenoarum. Anais da Academia Brasileira de Ciências. v. 89, p. 1753-1760, 2017. Available from: $<$ https://www.scielo.br/j/aabc/a/M6BmNDtQPrBWJwqmLXdB xXn/?lang=en>. Accessed: May. 03, 2021. doi: 10.1590/00013765201720160662 .

STOBBS, T. H. The effect of plant structure on the intake of tropical pastures. I. Variation in the bite size of grazing cattle. Crop and Pasture Science, v. 24, p. 809-819, 1973. Available from: $<$ https:// www.publish.csiro.au/cp/AR9730809>. Accessed: Oct. 10, 2020. doi: 10.1071/AR9730809.

STRECK, E. A. et al. Variabilidade fenotípica de genótipos de arroz irrigado via análise multivariada. Revista Ciência Agronômica, v. 48, p. 101-109, 2017. Available from: $<$ http://ccarevista.ufc.br/seer/index.php/ccarevista/article/ view/4392/0>. Accessed: May. 05, 2021. doi: 10.5935/18066690.20170011 .

SOLLENBERGER, L. E.; BURNS, J. C. Canopy Characteristics, Ingestive Behaviour and Herbage Intake in Cultivated Tropical Grasslands. In: INTERNATIONAL GRASSLAND CONGRESS, 19., 2001, São Pedro. Proceedings... Piracicaba: Fealq, São Pedro, 2001. p. 321-327.

TRINDADE, J. P. P.; ROCHA, M. G. Rebrotamento de capim caninha (Andropogon lateralis Nees) sob efeito do fogo. Ciência Rural, v. 31, p. 1057-1061, 2001. Available from: $<$ https://www.scielo.br/scielo.php?script=sci_arttext\&pid $=\mathrm{S} 0103-8478200100060002>$. Accessed: Oct. 10, 2020. doi: 10.1590/S0103-84782001000600023.

WEILER, R. L. et al. Intraspecific tetraploid hybrids of Paspalum notatum: agronomic evaluation of segregating progeny. Scientia Agricola, v. 75, p. 36-42, 2018. Available from: $\quad<$ https://www.scielo.br/scielo.php?script=sci arttext\&pi $\mathrm{d}=\mathrm{S} 010390162018000100036>$. Accessed: Oct. 22, 2020. doi: $10.1590 / 1678-992 x-2016-0354$. 